УДК 371.134: 811.1/.2 + 81’24 (045)

Рацул Олександр Анатолійович

кандидат педагогічних наук, доцент, доцент кафедри соціальної педагогіки та психології факультету педагогіки та психології

Кіровоградський державний педагогічний університет імені Володимира Винниченка, м. Кіровоград, Україна

ratsul@i.ua

\title{
ІНФОРМАЦІЙНА КУЛЬТУРА ЯК СОЦІАЛЬНА ЯКІСТЬ МАЙБУТНІХ СОЩІАЛЬНИХ ПЕДАГОГІВ
}

\begin{abstract}
Анотація. Статтю присвячено висвітленню сутності інформаційної культури як соціальної якості майбутніх соціальних педагогів в аспекті їі системного розвитку у професійних, освітніх, неформальних соціумах. Визначено умови забезпечення системного розвитку інформаційної культури в майбутніх соціальних педагогів. Схарактеризовано загальні напрями (принципи) діяльності на різних етапах процесу системного розвитку інформаційної культури майбутніх соціальних педагогів. Виокремлено низку умов, які детермінують системний розвиток інформаційної культури майбутніх соціальних педагогів. Запропоновано групи функціональних показників для проведення якісної діагностики вихідного рівня оволодіння інформаційною культурою у майбутніх соціальних педагогів.
\end{abstract}

Ключові слова: інформаційна культура; майбутні соціальні педагоги; інформатизація освіти; навчальний процес; освітній процес.

\section{1. ВСТУП}

Постановка проблеми. Визначальною рисою сучасного етапу розвитку суспільства $є$ формування нового інформаційного середовища, укладу життя, що впливає на ефективний розвиток творчого потенціалу особистості, й вимагає від системи вищої професійної освіти розв'язання завдань розвитку нового типу інтелекту, нового інформаційного світогляду, котрий грунтується на розумінні визначальної ролі інформації й інформаційних процесів у природних і соціальних явищах, інформаційної культури майбутніх громадян країни, створення іншого образу і способу мислення майбутніх фахівців соціальної сфери, пристосованих до швидко змінюваних економічних, технологічних, соціальних та інформаційних реалій навколишнього світу.

Будь-яка сфера соціальної практики реалізується 3 урахуванням суспільних перетворень, які відбуваються в соціумі, у самій особистості, у різних групах людей. Це і є способом передавання інформації і культурного досвіду від одного покоління до іншого, носієм якого є фахівець як особистість й індивідуальність. Ураховуючи те, що системний розвиток інформаційної культури (IК) майбутніх соціальних педагогів відбувається в усіх галузях суспільної практики, основний акцент робиться на створення й розвиток інформаційно-розвивального освітнього середовища вищого навчального закладу (ВН3), активізацію соціумних чинників, які впливають на сформованість IК викладачів і майбутніх соціальних педагогів.

Таке формулювання питання актуалізує проблему IК майбутніх соціальних педагогів і включає розмаїття аспектів, пов'язаних із людиною і її соціумом, системою вищої професійної освіти, а також необхідну сукупність особистісних якостей майбутнього фахівця, його соціально-педагогічний та інформаційно-комунікаційний потенціал, які дозволяють вільно використовувати у своїй професійній діяльності інформаційні засоби й об’єкти щодо конкретної особистості, соціальної групи, 
колективу, соціуму (Р. С. Гуревич [3; 2], М. І. Жалдак [4], О. Карабін [5], А. М. Коломієць [7; 8], М. Левшин [9], Н. В. Морзе [10]).

Аналіз досліджень і публікацій. Проблемі IК фахівців різного профілю присвячено низку робіт науковців, велику частину котрих написано в руслі концепцій постіндустріалізму. Серед них слід зазначити роботи Д. Белла, К. Вербаха, Р. Кана, Е. Кінга, І. Масуда, Т. Меррілла, М. Пората, Л. Робертса, К. Робінсона, Р. Реддіка.

Особливий внесок у розроблення методологічних проблем системного розвитку IК внесли А. А. Гречихін, Н. Б. Зинов'єва, А. І. Ракитов, Е. П. Семенюк, В. А. Фокеєв, Ю. А. Шрейдер.

Змістовні аспекти формування IK особистості розглядалися в працях А. А. Виноградова, Д. В. Зарецького, А. Г. Кушніренко, О. А. Медведєвої, Ю. А. Первиніна, А. І. Ракитова, В. В. Самохвалової.

Осмислення й узагальнення накопичених знань з теорії ІК у контексті соціальнопедагогічних поглядів закладено в роботах $\quad$ В. Г. Бочарової, $\quad$ М. П. Гур'янової, В. І. Загвязинського, А. В. Мудрик, О. Г. Прохорової, М. І. Рожкова, В. О. Сластьоніна, Г. Г. Силласте, В. С. Торохтій, О. І. Холостової, Т. Ф. Яркіної та ін.

Мета статті. За мету статті поставлено завдання дослідити, як відбувається в навчальному процесі процес системного розвитку ІК майбутніх соціальних педагогів і прояв IК як їх соціальної якості.

\section{2. РЕЗУЛЬТАТИ ДОСЛІДЖЕННЯ}

Системний розвиток IK майбутніх соціальних педагогів розглядається в особистісному, громадському та професійному планах. Як особистісний феномен IК окремого майбутнього соціального педагога своєрідно переломлює у собі весь його внутрішній світ i, передовсім, його інтелектуальний складник. Чим багатшим $\epsilon$ внутрішній світ особистостей майбутніх соціальних педагогів, тим сприятливішими $\epsilon$ умови для системного розвитку ІК. ІК майбутніх соціальних педагогів певним чином корелює 3 обсягом інформації, якою вони володіють. Проте це співвідношення не носить характер прямої пропорційної залежності, воно $\epsilon$ складнішим i неоднозначнішим.

Становлення особистої IК майбутніх соціальних педагогів відбувається неперервно в різних соціумах (професійних, освітніх, неформальних) і залежить від особливостей конкретної соціально-педагогічної інфраструктури, котра є сукупністю матеріальних і технічних засобів, організаційних структур і умов, які забезпечують за допомогою внутрішнього кадрового потенціалу соціально-педагогічну діяльність установ й організацій держави, суспільства, регіону, міста, конкретного соціального інституту того чи того соціуму.

3 одного боку, цей процес структурується, організовується та спрямовується системами навчання й виховання, а, з іншого, - ІК формується в процесі повсякденної професійної діяльності під упливом засвоєння знань і вмінь, інформації засобів масової комунікації, у процесі спілкування, самоосвіти. Особливо підкреслимо вплив сучасної інформаційної техніки на формування й розвиток професійної компетентності майбутніх соціальних педагогів, яка детермінується істотним розширенням обсягу й характеру доступної інформації, форм іiї отримання й перетворення.

ІК майбутніх соціальних педагогів $є$ особливим «зрізом» їх професійної культури, котра репрезентує системну сукупність знань, умінь i навичок для пошуку й використання інформації з метою вдосконалення особистої майстерності й досягнення вищої ефективності професійної діяльності. 
Формування професійної компетентності майбутніх соціальних педагогів знаходиться в тісному взаємозв'язку і взаємозалежності від IК особистості, фахівця й суспільства, з потенціями конкретного соціуму. Вивчення результатів наукових досліджень, виконаних у контексті професійної підготовки фахівців соціальної сфери, демонструє, що ці питання є досить важливими для практичної діяльності в різних соціумах.

У межах соціально-педагогічної моделі системного розвитку ІК майбутніх соціальних педагогів нами було визначено умови забезпечення сталого розвитку в них IK, які включають:

а) загальні напрями (принципи), пов’язані 3 розвитком навчально-виховного процесу в системі вищої професійної освіти 3 урахуванням соціальної взаємодії (зовнішньої і внутрішньої);

б) способи їх реалізації.

Загальні напрями (принципи) діяльності слід визначати на різних її етапах:

1) «у вихідній позиції» - під час комплектування контингенту майбутніх соціальних педагогів, які навчаються за спеціальностями, котрі є актуальними для соціальної сфери;

2) на етапі «реалізації освітнього процесу у ВНЗ»;

3) на «виході» — під час випуску фахівців.

Загальні напрями (принципи) діяльності визначаються, виходячи 3 того, що в результаті цієї діяльності має забезпечуватися підтримання чинників, які позитивно впливають на стійкість системного розвитку ІК майбутніх соціальних педагогів.

До загальних напрямів (принципів) діяльності належать подані нижче.

1. Забезпечення наступності навчання майбутніх соціальних педагогів у системі вищої професійної освіти.

2. Посилення соціальних взаємодій у навчанні, котрі припускають забезпечення внутрішньої причетності майбутніх соціальних педагогів, їх батьків, наставників на базах практики, роботодавців тощо до організації та змісту навчальної і позанавчальної роботи ОУ. Ця умова, здійснювана на етапі «реалізації» освітнього процесу, сприяє підтриманню педагогічного чинника.

3. Забезпечення відповідності випускників закладу вищої професійної освіти потребам соціальної сфери регіону. Ця умова, чинна на «виході» 3 освітнього процесу, сприяє підтриманню соціально-педагогічного чинника.

Для майбутніх соціальних педагогів особливо зазначимо, що інформаційна компетентність безпосередньо корелює із соціально-педагогічною. Соціальнопедагогічна компетентність, за визначенням Н. Ю. Клименко, передбачає необхідну сукупність особистісних якостей майбутніх соціальних педагогів, котрі дозволяють їм орієнтуватися й адаптуватися в динамічно мінливому соціумі, у середовищі, i максимальне використання потенціалу професійного мікросередовища, суспільства [6, c. 67].

Сучасні соціальні педагоги мають володіти технологіями не лише отримання, опрацювання та зберігання інформації, а й більшою мірою iï аналізу. У соціальнопедагогічній роботі розуміння можливостей фахівця тісно пов'язане 3 умінням ефективно матеріалізувати інформаційний потенціал за допомогою організації своїх дій або сукупності дій фахівців-суміжників [12, с. 65].

В умовах інформатизації освіти зростає значення розвитку інформаційнокомунікаційної компетентності фахівців будь-якого профілю. Інформаційнокомунікаційна компетентність майбутніх соціальних педагогів має на увазі адаптивність, вільне володіння вербальними й невербальними засобами спілкування, ставлення до пізнавальної діяльності, природного й соціального світу, самого себе. 
Практика підтверджує, що останнім часом виник новий вид грамотності комп'ютерна грамотність: без уміння працювати з комп'ютером нині вже практично неможливо отримати престижну й високооплачувану роботу, скористатися новими електронними послугами, замовити літературу, квитки, здійснити операції зі своїм банківським рахунком тощо.

Для майбутніх соціальних педагогів найважливішою $\epsilon$ інформаційнокомунікаційна компетентність, яку А. В. Вишнякова розглядає, як володіння навичками пошуку й систематизації інформації, її електронного опрацювання, перекладу з однієї знакової системи на іншу (текст, мапа, таблиця, схема, аудіовізуальний ряд), участі в обговоренні проблем, у тому числі й визначення вузлових моментів дискусії, формулювання власної позиції з обговорюваних питань і використання відомостей для iii аргументації, уміння публічно презентувати результати своєї роботи, добираючи адекватні форми й методи презентації. Вона виокремлює такі найзначиміші компоненти інформаційно-комунікаційної компетентності [1, с. 14]:

a) цілісне світорозуміння й науковий світогляд, які грунтуються на розумінні єдності основних інформаційних законів у природі й суспільстві, можливості їх формального, математичного опису;

б) уявлення про інформаційні об'єкти і їх перетворення в людській практиці, у тому числі й за допомогою засобів IКТ, технічних і програмних засобів, які реалізують ці технології;

в) сукупність загальноосвітніх і професійних знань і вмінь, соціальних й етичних норм поведінки людей в інформаційному середовищі.

Для системного розвитку ІК майбутніх соціальних педагогів мають виконуватися такі умови:

а) відповідність змісту навчальних планів і програм тенденціям розвитку IКТ у соціально-педагогічній діяльності;

б) впровадження нових ІКТ у вищу освіту;

в) формування у майбутніх соціальних педагогів професіоналізму в оволодінні засобами інформатики й обчислювальної техніки і здатності використання нових IКТ за профілем діяльності;

г) високий рівень професійної підготовки викладачів - фахівців не лише в галузі IKT, а й усіх викладачів, метою котрих має стати впровадження технологій, покликаних розширювати межі застосування ІКТ у різних конкретно-предметних галузях.

г) наявність сучасної технічної (комп’ютерної) бази ВНЗ.

Розвиток інформаційно-комунікаційної компетентності $\epsilon$ постійним i суперечливим становленням, зміною під упливом зовнішніх (сім'я, ВНЗ, засоби масової комунікації, культура тощо) чинників. Розвиток інформаційно-комунікаційної компетентності майбутніх соціальних педагогів уможливлюється лише в діяльності, тому навчально-пізнавальна діяльність розглядається, як підгрунтя розвитку цієї якості [11, c. 12].

Як складна багатофункціональна структура, котра складається 3 компонентів, котрі знаходяться в неперервному динамічному розвитку і взаємодії, IК майбутніх соціальних педагогів не може бути раз і назавжди зафіксованою у вигляді еталона або зразка поведінки, чітко позначених характеристик мислення і свідомості, універсальних форм міжособистісної комунікації і професійної діяльності, оскільки вона сприймається, опановується й відтворюється кожним майбутнім соціальним педагогом індивідуально і своєрідно.

Разом із тим, діяльнісний підхід і блочно-модульний принцип навчання, спрямовані на диференціацію й індивідуалізацію навчального процесу, актуалізують механізми внутрішньої саморегуляції людини і сприяють екстеріоризації 
індивідуальних переваг, настанов, цінностей, їх активного прояву в спеціальних навчальних ситуаціях, а отже, за своєю сутністю, є діагностичними.

Для проведення якісної діагностики вихідного рівня оволодіння IК у майбутніх соціальних педагогів рекомендується використовувати такі групи функціональних показників:

а) інформаційна активність;

б) інформаційний стиль мислення;

в) емоційна активність;

г) світоглядна активність.

Ці функціональні показники відбивають оволодіння окремими рівнями IК майбутніх соціальних педагогів відповідно до ії̈ змісту.

Конкретизуємо запропоновані функціональні показники з точки зору їх прояву в групах з основним, професійним і вищим логічним рівнем ІК й опишемо психологопедагогічний інструментарій, який застосовується в процесі діагностики.

Інформаційна активність. Для основного рівня характерними $є$ :

а) несформованість інформаційних потреб й інтересів;

б) мінімальний обсяг тезаурусу;

в) репродуктивний характер знань.

Зацікавленість майбутніх соціальних педагогів в отриманні нових знань обумовлена лише потребою скласти іспит чи залік. Для професійного рівня характерним $\epsilon$ підвищення творчої активності майбутніх соціальних педагогів. Зацікавленість в отриманні нових знань служить підгрунтям розвитку ускладнюваної системи інформаційних потреб й інтересів. Обсяг тезаурусу є значним, знання мають продуктивний характер. Майбутні соціальні педагоги усвідомлено сприймають інформацію, грамотно оперують поняттями. Однак, звернення до позапрограмного матеріалу має поки що епізодичний характер. Вищий рівень характеризується найвищою творчою активністю, розвиненою широкою системою стійких і спрямованих інформаційних потреб й інтересів, розпредмеченими знаннями, умінням оцінювати процеси й явища, котрі відбуваються в інфосередовищі на грунті індивідуальноосмислених й особистісно-прийнятих культурних цінностей. Студенти цієї групи регулярно читають додаткову літературу 3 фаху, їх тезаурус вирізняється великою ємністю.

Як важливий критеріальний показник IK майбутніх соціальних педагогів позначено інформаційний стиль їх мислення. У розгляді цього показника рівневі групи майбутніх соціальних педагогів визначалися за низкою характеристик.

Основний рівень. Майбутні соціальні педагоги цієї групи недостатньо добре володіють методами аналітико-синтетичного опрацювання інформації. Вони відчувають складнощі в доборі інформації, часто неправильно іiі інтерпретують і не завжди можуть використовувати отриману інформацію для розв'язання інформаційнопрофесійних завдань. Вони не вміють швидко згортати й розгортати інформацію, добудовувати відсутні ланки. У них слабко розвинені якісна оцінка інформації і здатність до узагальнення, систематизації, оцінювання інформації.

Професійний рівень. Майбутні соціальні педагоги цієї групи здатні обрати 3 потоку інформації достовірні дані і співвіднести їх з уже набутими знаннями. Вони добре володіють навичками аналітико-синтетичного опрацювання інформації, мають широкий світогляд, правильно оцінюють якісний аспект інформації. На цьому рівні у майбутніх соціальних педагогів інтенсивно формується система інтелектуальних здібностей:

а) аналітичне мислення; 
б) уміння виявляти зв’язки й відносини між окремими елементами інформаційного знання;

в) вміння узагальнювати, систематизувати, логічно виводити нове знання з уже засвоєного, оцінювати отриману інформацію 3 позицій накопиченого суспільнокультурного досвіду.

Вищий рівень. Майбутні соціальні педагоги цієї групи вільно володіють методами аналітико-синтетичного опрацювання інформації. Їх характеризує висока культура мислення (гармонійне поєднання алгоритмічного й рефлексивного типів мислення). Вони швидко і правильно оцінюють нову інформацію, у них добре сформовано навички психогігієни інформації і захисту від інформаційного шуму. Під час розв'язування інформаційно-професійних завдань й оцінювання альтернатив майбутні соціальні педагоги враховують раціональні, естетичні й морально-етичні критерії, модулюючи і прогнозуючи наслідки прийнятих рішень в інтересах розвитку суспільства.

Наступний показник сформованості IК - це емоційна активність. Первинна реакція на значимість для особистостей майбутніх соціальних педагогів будь-якої інформації, ऑiі інтуїтивне оцінювання, безпосередня сигналізація про ступінь задоволення потреб особистостей майбутніх соціальних педагогів, співпереживання у процесі інформаційного обміну — це не лише відображення емоційного рівня IК майбутніх соціальних педагогів, а й спонукання до діяльності. Виховати почуття — це означає виховати у майбутніх соціальних педагогів активний позитивно забарвлений емоційний пошук ціннісних форм споживання інформації. Щодо рівневих груп характеристики емоційної активності було розподілено нами так.

Для основного рівня емоційної активності майбутніх соціальних педагогів характерна орієнтація на отримання виключно особистого, емоційного задоволення від інформації. Рівень вимог до якісного, змістовного аспекту інформації $є$ невисоким. Джерело інформації у більшості випадків розглядається, як предмет, котрий викликає лише емоційне задоволення (телесеріали типу «мильних опер», любовні й детективні бестселери). Прояв соціальних, вищих почуттів розвинений слабко й не відіграє суттєвої ролі в діях і вчинках.

Для професійного рівня емоційної активності майбутніх соціальних педагогів характерною є регулювальна роль вищих соціальних почуттів. Особистості майбутніх соціальних педагогів здатні критично оцінювати інформацію, визначати эї якісний аспект. Джерело інформації розглядається, у першу чергу, як предмет задоволення пізнавальних потреб. Стан інформованості майбутніх соціальних педагогів супроводжується почуттям психологічного комфорту, впевненістю і пов'язаний із підвищенням соціального статусу i кваліфікації. Емоційна активність набуває складнішу форму. Тут відіграє роль і розширення змістовності почуттів й емоцій, і їх ціннісна орієнтація.

Для вищцого рівня емоційної активності майбутніх соціальних педагогів характерною $є$ цілісність іï структури та змісту, котра вирізняється глибиною та всебічною розвиненістю. Емоційна активність майбутніх соціальних педагогів стає інструментом творчого оволодіння, споживання й використання інформації. Майбутні соціальні педагоги цієї групи регулюють свою інформаційну діяльність за допомогою вищих почуттів - інтелектуальних, морально-етичних й естетичних. На цьому рівні емоційна активність виконує функції регулятора ціннісної орієнтації почуттів й емоцій майбутніх соціальних педагогів у структурі їх IК.

I, нарешті, інформаційна світоглядна активність, яка свідчить про певний рівень розуміння особистостями майбутніх соціальних педагогів свого місця в 
інформаційному суспільстві, цілей та ідеалів інформаційної діяльності, ролі процесів інформатизації у розвитку цивілізації.

Основний рівень характеризується сформованістю лише основ переконань й ідеалів як презентованих зразків. Майбутні соціальні педагоги цієї групи відчувають складнощі в продукуванні індивідуальних критично-оцінних суджень 3 приводу інформаційних явищ і процесів. Вони не володіють прийомами формулювання власних цілей інформаційної діяльності. Творча спрямованість цієї діяльності розвинена слабко.

Професійний рівень. Майбутні соціальні педагоги цієї групи вирізняються більшою впевненістю в адекватності своїх поглядів реальним процесам інформатизації, які відбуваються в суспільстві. У їх уявленні ідеали наповнюються конкретним суспільним змістом. Майбутні соціальні педагоги здатні сформулювати й аргументувати мету своєї інформаційної діяльності. Критерії оцінювання інформаційних явищ стають глибшими, гнучкішими й різноманітними. Творча спрямованість діяльності посилюється. Потреба реалізувати свої переконання усвідомлюється з позицій суспільної значимості.

Вищий рівень. Майбутніх соціальних педагогів цієї групи характеризує високий ступінь сформованості системи поглядів і відносин до реальних процесів інформатизації, а також цілісність ціннісних орієнтацій i настанов, яка свідомо реалізується в процесі їх інформаційної діяльності. Майбутні соціальні педагоги цієї групи є автономними й самостійними у своїх оцінках і судженнях щодо інформаційних явищ і процесів, свідомо й відповідально обирають мету своєї інформаційної діяльності й соціально прийнятні засоби іiі досягнення, здатні активно відстоювати свої переконання й позицію в ситуації боротьби цінностей і смислів, володіють прийомами творчого саморозвитку.

У цілому, завдання системного розвитку ІК особистостей майбутніх соціальних педагогів і підвищення масової ІК суспільства вимагає, на наш погляд, дотримання поданих нижче умов.

1. Використання можливостей усіх ланок системи неперервної освіти, починаючи 3 дошкільної та завершуючи післядипломною освітою, для системного розвитку ІК ісобистостей майбутніх соціальних педагогів. Наразі принципово важливим $\epsilon$ одночасне підвищення IК як викладачів, так і студентів. Способом системного розвитку IК особистостей майбутніх соціальних педагогів має стати інтегративний, діяльнісноорієнтований, побудований за блочно-модульним принципом курс «Інформаційна культура фахівця».

2. Взаємодія системи освіти 3 такими соціальними інститутами, які традиційно акумулюють інформаційні ресурси суспільства, як бібліотеки і служби інформації. Засобом, який забезпечує таку взаємодію, має стати єдиний методологічний підхід, який передбачає єдність понятійного апарату, знання основних законів функціонування документальних потоків: інформації у суспільстві, прийомів і методів аналітикосинтетичного опрацювання інформації, критеріїв ефективного пошуку інформації та низки інших чинників.

3. Організація спеціальної підготовки педагогічних кадрів, здатних на професійному підгрунті проводити заняття з курсу «Інформаційна культура фахівця» 3 різними категоріями студентів.

Отже, ІК майбутніх соціальних педагогів розглядається як складник базисної i професійної культури особистості, системна характеристика людьми фахівця, що дозволяє йому ефективно брати участь у всіх видах роботи з інформацією (отриманні, накопиченні, кодуванні й опрацюванні інформації будь-якого роду, у створенні на цьому підгрунті якісно нової інформації, iї передаванні, практичному використанні), що включає: 
a) грамотність і компетентність у розумінні природи інформаційних процесів $\mathrm{i}$ відносин;

б) гуманістично орієнтовану інформаційну ціннісно-смислову сферу (прагнення, інтереси, світогляд, ціннісні орієнтації);

в) розвинену інформаційну рефлексію;

г) творчість у професійній поведінці й соціально-інформаційній активності.

\section{3. ВИСНОВКИ ТА ПЕРСПЕКТИВИ ПОДАЛЬШИХ ДОСЛІДЖЕНЬ}

Отже, зміна соціально-економічної ситуації в Україні, інформаційний вибух, який спостерігається в усьому цивілізованому світі, припускають перегляд традиційно сформованих систем, методів і технологій професійної освіти. Одним із найважливіших завдань, які поставлено перед системою освіти, є виховання людини, котра володіє такими якостями, як творча активність, інформаційна культура, системне наукове мислення.

У процесі системного розвитку ІК майбутніх соціальних педагогів розв’язується соціально-педагогічне завдання, котре полягає в тому, щоб підготувати майбутніх соціальних педагогів до самостійної практичної діяльності, у якій вони можуть реалізовувати свої творчі здібності, застосовувати отримані знання, уміння й навички, а також продовжувати освіту й самоосвіту.

Перспективи подальших пошуків у напрямку дослідження. Виявлення й опис специфіки ІК як соціальної якості майбутніх соціальних педагогів має перспективу в плані дослідження соціально-педагогічних аспектів процесу системного розвитку ІК майбутніх соціальних педагогів у навчальному процесі.

\section{СПИСОК ВИКОРИСТАНИХ ДЖЕРЕЛ}

1. Вишнякова А. В. Образовательная среда как условие формирования информационнокоммуникативной компетентности учащихся: дис. ... канд. пед. наук : 13.00.01 / Вишнякова Анжелика Владимировна. - Оренбург, 2002. - 172 с.

2. Гуревич Р. С. Інформаційна культура педагога як необхідний компонент сучасної освіти / Р. С. Гуревич // Сучасні інформаційні технології та інноваційні методики навчання в підготовці фахівців: методологія, теорія, досвід, проблеми : зб. наук. пр. - К. - Вінниця : ТОВ Фірма «Планер», 2010. - Вип. 23. - С. 190-195.

3. Гуревич Р. С. Формування інформаційної культури майбутнього фахівця як невід'ємна складова сучасної професійної освіти // Педагогіка і психологія професійної освіти: результати досліджень ; за ред. І. А. Зязюна, Н. Г. Ничкало. - К. : [б. в.], 2003. - С. 354-360.

4. Жалдак М. І. Основи інформаційної культури вчителя / М. І. Жалдак // Використання інформаційних технологій в навчальному процесі. — К. : РНМК, КДПІ, 1990. - С. 3-17.

5. Карабін О. Інформаційна культура студентів в контексті модернізації педагогічної освіти / О. Карабін // Наукові записки Тернопільського національного педагогічного університету. Серія: Педагогіка. - 2005. - № 2. - С. 37-40.

6. Клименко Н. Ю. Социально-педагогическая компетентность - необходимая составляющая профессиональной деятельности каждого современного специалиста / Н. Ю. Клименко // Социальная педагогика в России. - № 1. - 2008. - С. 65-69.

7. Коломієць А. Міжпредметні та надпредметні проекти як спосіб розвитку інформаційної культури студента / А. Коломієць, Д. Коломієць // Педагогіка і психологія професійної освіти. — 2006. № 2. - C. 24-31.

8. Коломієць А. М. Основи інформаційної культури майбутнього вчителя / А. М. Коломієць, І. М. Лапшина, В. С. Білоус. - Вінниця : ВДПУ, 2006. - 88 с.

9. Левшин М. Педагогічна сутність поняття «інформаційна культура особистості» / М. Левшин // Вища освіта України. — 2002. - № 3. - С. 67-74.

10. Морзе Н. В. Інформаційна культура та іï складові [Електронний ресурс] / Н. В. Морзе. — Режим доступу: http://ped.sumy.ua/index.php?option=com_content\&view=article\&id=627. — Назва з екрану. 
11. Морковина Э. Ф. Развитие информационной компетентности студента в образовательном процессе: дис. ... канд. пед. наук : 13.00.01 / Морковина Эльвира Фаридовна. — Оренбург, 2005. $212 \mathrm{c}$.

12. Социально-педагогические технологии в деятельности образовательного учреждения: учебн. пособие для студ. вузов по специальностям «Социальная педагогика», «Социальная работа» / [под ред. В. С. Торохтий]. - М. : АНО «СПО «СОТИС», 2007. - 348 с.

Матеріал надійшов до редакиії 07.08.2014 p.

\title{
ИНФОРМАЦИОННАЯ КУЛЬТУРА КАК СОЦИАЛЬНОЕ КАЧЕСТВО БУДУЩИХ СОЩИАЛЬНЫХ ПЕДАГОГОВ
}

\section{Рацул Александр Анатольевич}

кандидат педагогических наук, доцент кафедры социальной педагогики и психологии факультета педагогики и психологии

Кировоградский государственный педагогический университет имени Владимира Винниченко, г. Кировоград, Украина

ratsul@i.ua

\begin{abstract}
Аннотация. Статья посвящена освещению сущности информационной культуры как социального качества будущих социальных педагогов в аспекте ее системного развития в профессиональных, образовательных, неформальных социумах. Определены условия обеспечения системного развития информационной культуры у будущих социальных педагогов. Охарактеризованы общие направления (принципы) деятельности на различных этапах процесса системного развития информационной культуры будущих социальных педагогов. Выделен ряд условий, детерминирующих системное развитие информационной культуры будущих социальных педагогов. Предложены группы функциональных показателей для проведения качественной диагностики исходного уровня овладения информационной культурой у будущих социальных педагогов.
\end{abstract}

Ключевые слова: информационная культура; будущие социальные педагоги; информатизация образования; учебный процесс; образовательный процесс.

\section{INFORMATIONAL CULTURE AS SOCIAL QUALITY OF FUTURE SOCIAL PEDAGOGISTS}

\author{
Oleksandr A. Ratsul \\ Ph.D. in Pedagogy, Associate Professor of Social Pedagogy and Psychology Department, \\ Faculty of Pedagogy and Psychology \\ Kyrovohrad Volodymyr Vynnychenko State Pedagogical University, Kyrovohrad, Ukraine \\ ratsul@i.ua
}

\begin{abstract}
The paper deals with the highlighting of the essence of informational culture as future pedagogists' social quality in the aspect of its system development in professional, educational, informal societies. The conditions of ensuring the systematic development of future social pedagogists' informational culture are defined. General directions (principles) of activity at different phases of the systematic development of future social pedagogists' informational culture are characterized. A number of conditions that determine the systematic development of future social pedagogists' informational culture is identified. Groups of functional indicators for conducting qualified diagnostics of the basic level of mastering of future social pedagogists' informational culture are proposed.
\end{abstract}

Keywords: informational culture; future social pedagogists; computerization of education; teaching process; educational process. 


\section{REFERENCES (TRANSLATED AND TRANSLITERATED)}

1. Vishnjakova A. V. Educational Medium as a Condition of Formation of Students' Informational-andCommunicative Competence: dis. ... cand. ped. sciences : 13.00 .01 / Vishnjakova Anzhelika Vladimirovna. — Orenburg, 2002. - 172 s. (in Russian).

2. Gurevych R. S. A Pedagogist's Informational Culture as a Necessary Component of Modern Education / R. S. Gurevych // Modern Informational Technologies and Innovative Teaching Methods in Training of Specialists: Methodology, Theory, Experience, Problems: col. of scient. works. - K. - Vinnicja : TOV Firma «Planer», 2010. — Issue 23. — P. 190-195 (in Ukrainian).

3. Gurevych R. S. Formation of a Future Specialist's Information Culture as an Integral Part of Modern Vocational Education // Pedagogy and psychology of vocational education: research results ; Ed. I. A. Zjazjun, N. G. Nychkalo. — K. : [b.v.], 2003. — P. 354-360. (in Ukrainian).

4. Zhaldak M. I. Basics of a Teacher's Information Culture / M. I. Zhaldak // Usage of Informational Technologies in the Teaching Process. - K. : RNMK, KDPI, 1990. - P. 3-17. (in Ukrainian).

5. Karabin O. Students' Information Culture in the Context of Pedagogical Education Modernization / O. Karabin // Scientific Notes of Ternopil National Pedagogical University. Series: Pedagogy. — 2005. — №2. - P. 37-40. (in Ukrainian).

6. Klymenko N. Ju. Socio-Pedagogical Competence - a Necessary Component of Every Modern Specialist's Professional Activities / N. Ju. Klymenko // Social Pedagogy in Russia. — №1. — 2008. — P. 65-69. (in Russian).

7. Kolomijets' A. Intersubject and Oversubject Projects as a Way of a Student's Information Culture Development / A. Kolomijets', D. Kolomijets' // Pedagogy and Psychology of Professional Education. - 2006. — №2. - P. 24-31. (in Ukrainian).

8. Kolomijets' A. M. Basics of a Future Teacher's Information Culture / A. M. Kolomijets', I. M. Lapshyna, V. S. Bilous. — Vinnycja : VDPU, 2006. - 88 s. (in Ukrainian).

9. Levshyn M. Pedagogical Essence of the Concept of "Informational Culture of a Person" / M. Levshyn // Higher Education of Ukraine. — 2002. — №3. - P. 67-74. (in Ukrainian).

10. Morze N. V. Informational Culture and Its Components [online] / N. V. Morze. - Available from: http://ped.sumy.ua/index.php?option=com_content\&view=article\&id=627. — Title from screen. (in Ukrainian).

11. Morkovina E. F. Development of Students' Informational Competence in the Educational Process: dis. ... cand. ped. sciences : 13.00.01 / Morkovina El'vira Faridovna. — Orenburg, 2005. — 212 s. (in Russian).

12. Socio-Pedagogical Technologies in Activities of an Educational Establishment: Manual for Students of Higher Educational Establishments in Specialities "Social Pedagogy", "Social Work" / [Ed. V. S. Torohtij]. — M. : ANO «SPO «SOTIS», 2007. — 348 s. (in Russian). 